\title{
InTERgenerational Transmission OF Trauma in SPIEgelman's MaUS
}

\begin{abstract}
This paper applies the concept of intergenerational transmission of trauma and Marianne Hirsch's concept of postmemory to Art Spiegelman's graphic novels Maus I: A Survivor's Tale: My Father Bleeds History and Maus II: A Survivor's Tale: And Here My Troubles Began. It distinguishes between the vicarious trauma that was passed on to the narrator-protagonist Art and mediated to him by his father Vladek, the Holocaust survivor, and Art's personal trauma caused by his mother's suicide, reflected in Spiegelman's cartoon "Prisoner on the Hell Planet". It deals with the level of Art's identification with the victims of the Holocaust, pointing out the narrator's distance from this trauma and contrasting it with the nature of his original personal trauma, expressed in a different graphic and textual style. A significant part of the paper is devoted to analyzing the presentation of the Nazi genocide in the form of comics. We argue that the social status of this medium contributes to the narrator's uncertainty about its appropriateness and adequacy to express the tragedy of the Holocaust in its complexity. Finally the paper focuses on the connection between intergenerational transmission of trauma and the question of identity in relation to the protagonist of Maus.
\end{abstract}

Key words

Holocaust; trauma; transmission of trauma; postmemory; Art Spiegelman; Maus; comics

Holocaust fiction by "post-Holocaust generation" or "second generation" writers raises a significant question regarding the intergenerational transmission of trauma; as Amy Hungerford asks succinctly, "How can the children of survivors be survivors themselves?" (2003: 92). One of the literary responses to this question was given by Art Spiegelman in his two-volume comic book or graphic novel Maus (the 
$1^{\text {st }}$ volume subtitled A Survivor's Tale: My Father Bleeds History was published in 1986, the $2^{\text {nd }}$ volume subtitled A Survivor's Tale: And Here My Troubles Began came out in 1991). ${ }^{1}$ Maus depicts how the trauma experienced by Art's father Vladek, a Holocaust survivor, is passed on to his son, a writer and cartoonist born after World War II. Regardless of the degree of the absorption and internalization of this historical and personal trauma, it is possible to say that the transmission of the cataclysmic wartime experiences across generations has formed a significant part of the identity of the children of survivors, and has become one of the crucial constituents of their Jewishness, regardless of the extent of their assimilation. Art's story confirms the assertion that generations which have never been exposed to a traumatic event can 'inherit' the trauma of their ancestors and that the most common channel of this intergenerational and transgenerational transmission is through the family. Spiegelman's book mirrors Art's fraught, very complicated relationship with his father, and, although his autobiographical character ${ }^{2}$ shows a certain resistance to his identification with Vladek's experience, and sometimes even appears to lack empathy towards his suffering, there is no doubt that this trauma is grafted onto his psyche. He undergoes what LaCapra calls "empathic unsettlement" and/or "muted trauma" (2001: 43-85).

Maus has a dual narrative structure; the sections set in present day Rego Park in New York (but also in the Catskill Mountains and Vermont) are narrated by Art, while those set in the past, located primarily in Poland before and during World War II, are described by Vladek, although there are situations in which Vladek abruptly switches to the present. This typically happens in cases where he wishes to avoid talking about particularly unpleasant events from his past, or, more importantly, in cases where the events of the past determine his present identity.

Since Art has no direct experience of the Holocaust, the tragic events are mediated to him through interviews with his father which Art records on tape. During these interviews, Vladek reenacts his suppressed trauma as brought about by the loss of almost his entire family. Art, the secondary witness, receives the history of the Holocaust and re-interprets it by rewriting Vladek's testimony in the form of a comic book. In doing so, he acquires what can correspond to Marianne Hirsch's concept of postmemory, which "is distinguished from memory by generational distance and from history by deep personal connection" (Hirsch 1997: 22). Certain problems with the acceptance of this term stem from the fact that it seems to signify a time after or beyond memory, but the term proves to be very useful since it distinguishes memory acquired from personal experience of an event from vicarious memory which is passed down to the following generation(s). According to Hirsch, "[p]ostmemory characterizes the experience of those who grow up dominated by narratives that preceded their birth, whose own belated stories are evacuated by the stories of the previous generation shaped by traumatic events that can be neither understood nor recreated" (Hirsch 1997: 22). ${ }^{3}$ It is not coincidence that the concept of postmemory arose in connection with Holocaust studies because of the centrality of the genocide for the children of survivors who 'remembered' the events not lived through. Postmemory reflects the level of iden- 
tification with the original recipients of trauma and is often characterized by the feeling of displacement, living in temporal and spatial exile, estrangement and the experience of a lack and absence which frequently leads to an identity crisis. The graphic interpretation of testimony in Maus is, to some extent, a synthesis of the memory and postmemory of the Nazi genocide. Spiegelman's work belongs to those texts that articulate a "complex intersection between identity, the past, memory, and culture and, centrally, they concern the process by which identification takes place and then is developed" (Eaglestone 2004: 81). ${ }^{4}$

Spiegelman's generational distance from events of which he has no firsthand experience is visible in the form of the book itself: in his drawings, he uses animals to represent people of individual nations. Consequently, mice represent Jews, cats denote Germans, pigs are used for gentile Poles, dogs signify Americans, frogs the French, and so on. In using anthropomorphic animals, Spiegelman uses cartoon conventions, in particular the antagonism between cats and mice, to express the nature of predatory perpetrators, victims and bystanders. More importantly, the distancing technique of using animal figures enables him to avoid a total identification with the Holocaust, and hence to forestall the ethically unacceptable appropriation of an event he has not lived through.

Considering the authorial distance from the past, it is significant that the only section of the book in which characters are depicted as humans and not as animals is Spiegelman's comix ${ }^{5}$ insert "Prisoner on the Hell Planet". This comic strip, created in the artist's early career, appears in the $1^{\text {st }}$ volume of Maus and strikes the reader by the contrast in its graphic style. Here the distance is nullified, because Art presents the trauma which he experienced personally following his mother's suicide in 1968. For him, the memory of this family tragedy is still too vivid; it was not mediated but experienced deeply, and thus there is no need for the author to distance himself from it by formal means. Yet he connects this tragedy with the Holocaust, because his mother's death can be said to complete the violent annihilation of his family. After all, "[f]acing Holocaust history for Art Spiegelman is [...] an attempt to recover family history and to touch the enormity of mass death through single life stories" (Franciosi 2003: 1202).

In revisiting this trauma while writing the comic book, Art's sense of guilt is only aggravated further, because he is aware of the fact that he has failed to meet his parents' expectations and has become a source of disappointment for them. What is more, he becomes aware of the lack of empathy he demonstrated towards his mother, and he feels that his failure to understand her contributed to her sense of loneliness. In his reenactment of the last encounter with his mother before her suicide, he remembers her asking him: "Artie...you...still...love...me...don't you?" (Spiegelman 1986: 103, ellipses in original). His insensitive reaction still hurts him: "I turned away, resentful of the way she tightened the umbilical cord: 'Sure, ma!'” (1986: 103). Art's remorse is made worse by the fact that his mother left no suicide note.

The connection between Art's personal trauma and the Holocaust is even more obvious in a frame which shows the grieving Art as a prisoner as if he himself 
were in a death camp. The picture is dominated by the naked body of his mother in the coffin and contains a swastika sign on a camp wall and a pile of murdered victims at its bottom. Moreover, the mother's protruding hand grasping a razor at the left bottom edge of the frame has a tattooed prisoner's number. Art's outcries "Hitler did it!", "Mommy!" and "bitch" (1986: 103) manifest his attempt to transfer his guilt on the other persons and thus to relieve his traumatized consciousness. However, relief is impossible; moreover, his feeling of guilt is reinforced by a family friend blaming Artie for the whole tragedy. At the same time Art is recognizing that his emotional estrangement from his mother's suffering is a transmitted effect of the original genocidal violence. In this respect, Hitler did this too, and continues to perpetrate acts of violence and suffering through the generations. The accusatory tone of Art's discourse culminates in the last panel when he even criminalizes her: "You murdered me, mommy, and you left me here to take the rap!!!" (1986: 103). However, he is admonished by the other prisoners, who manifest their indifference to his original trauma: "Pipe down, Mac! Some of us are trying to sleep!" (1986: 103).

Despite Art's accusation of his mother we should read Spiegelman's comix, a product of his underground involvement in art, as an expression of love for her and of his wish that she be alive. More importantly, it expresses his regret over what he should have done and has not. As a matter of fact, his narrative is permeated by self-accusation; he ruminates that he might have saved her if he had got home when expected and if he had not been resentful to her attempt to tighten their emotional bond, or, in other words, if he had not suppressed love for her. He feels responsibility for her death because he realizes that his resentment, be it a pose or a sign of the alienation from his parents, could be interpreted as a betrayal. Furthermore, he knows that he became a disappointment for his parents - his treatment in a mental hospital before his mother's suicide must have been frustrating for both parents.

The initial frame of "Prisoner on the Hell Planet" with the photograph of a smiling small Artie with his mother, taken near Trojan Lake, New York, in 1958, seemingly contrasts with the depressing ambience of Spiegelman's comix insert. However, the fingers holding the photograph imply that the narrator's happiness vanished in the distant past and Art's nostalgia for idyllic (though transitory) moments of his childhood forms a prelude to the acting out of the tragic event that has deeply scarred his psyche. For Spiegelman the creation of this comix itself represented an enactment of the painful family history that might have therapeutic effects but that also caused the tension between him and his father after Vladek had accidentally discovered his son's juvenile work. Art's planet, which he revisited after the original trauma, is too dark and stark, inhabited by despondent people in the state of the highest despair. Their faces with blunt looks, cries and screams may remind us of paintings by Goya or Munch. ${ }^{6}$ In their visual expression, they are paradoxically more frightening than the figures from Auschwitz in Vladek's narrative.

Stylistically and graphically, "Prisoner on the Hell Planet" differs from the other part of Maus not only by the depiction of characters as humans (though 
they look almost inhuman) and by the black color of its pages but especially by its fragmentary character. Expressionistic style noticeably contributes to the extremely emotional charge of Spiegelman's cartoon that is in a stark contrast with the rather detached, understated style of Vladek's and Artie's narratives in both volumes of Maus. Fragmentation also characterizes Vladek's narrative, yet due to his temporal distance from the original trauma, the fragmentation of his narrative does not seem to be so extreme. The fragmentary character of Art's cartoon is in accord with the nature of trauma. It is derived not only from the high emotionality linked with the traumatic topic but especially from the inaccessibility of the original trauma that cannot be fully grasped or integrated into his consciousness. As Cathy Caruth says, "the most direct seeing of a violent event may occur as an absolute inability to know it" (1996: 92). Although Art did not witness the violent scene directly (otherwise he would have prevented it), he is naturally overwhelmed by the totally unexpected death of his mother.

Throughout the whole work, Art's depression arises from his feelings of incompetence, which only intensifies his feeling of guilt. ${ }^{7} \mathrm{He}$ is convinced that he is nothing more than an imperfect surrogate of his brother Richieu who was killed during the war. Although he could never have met him personally because Art was born after the war, he knows he will never emerge from his brother's shadow. Such a traumatizing impact of a killed sibling on somebody born after his or her death is not exceptional; for example Gabriele Schwab in her book Haunting Legacies: Violent Histories and Transgenerational Trauma confesses: "It was during my psychoanalytic training analysis that I was finally able to confront what I had vaguely known all along: so much of my life was shaped by an older brother who died as an infant during World War II, before I was born" (2010: 119). She admits she felt guilty for living her life at the expense of her dead infant brother. In the body of psychoanalytic literature children with a similar experience are termed "replacement children" and Art can be classified as one of them. The fact that his parents keep a photograph of Richieu in their bedroom, but no pictures of him only confirms his sense of being an outsider, an imperfect substitute for his perfect brother who makes him jealous many years after his death. He calls Richieu "my ghost brother" (Spiegelman 1991: 15), and he is indeed haunted by the specter of him. As Sicher argues, "Richieu is the absent presence in the home that makes Art feel guilty and inferior" (2005: 148). Though Art is aware of the absurdity of the rivalry with his dead brother, he is unable to overcome his feelings of inferiority. As a "replacement child" he fills a void, an empty space left after Richieu's violent death and like the other intergenerational and transgenerational recipients of the trauma of the Holocaust, he faces the problem of confusion about his identity. Art's traumatic competition with his brother reaches its ironic climax at the end of the $2^{\text {nd }}$ volume, when his seriously ill and disoriented father confuses him with Richieu, asking him: "Let's stop, please, your tape recorder... I'm tired from talking, Richieu, and it's enough stories for now..." (136, ellipses in original). As Schwab suggests, "[t]his tacit competition with a dead sibling is a classical syndrome of replacement children. It is also 
a prevalent form in which parental trauma is transmitted to the next generation and often to generations to come" (2010: 121).

Art's 'inheritance' of his parents' trauma leads to his obsession with the Holocaust, although he is at pains to deny that it is an obsession. Vladek's and Anja's past forms an important part of his identity. Victoria A. Elmwood speaks of "the author's need to write himself into a family from whose founding trauma he was absent" (2004: 691). His identification with his parents' affliction becomes so intense that he starts imagining being in Auschwitz. He recalls his perverse dreams from childhood about Nazi soldiers storming into his classroom and dragging away all the Jewish pupils, and he fantasizes about Zyklon B coming out from the shower of their bathroom instead of water (Spiegelman 1991: 16). His awareness that he did not live through the Holocaust contributes to his feelings of incompetence. Put simply, Richieu was there, while he was not! Artie seems to be disqualified for his 'combat' with his brother because he knows that unlike Richieu, he does not share his parents' tragic past. It is important to note that Art's dead brother figures as a photograph. The photograph functions as a memorial paying tribute to the ideal child who may "have become a doctor, and married a wealthy Jewish girl", however for Art "it's spooky, having sibling rivalry with a snapshot!" (1991: 15) since he is aware of his imperfection that lowers his social status in the family hierarchy. According to Elmwood, this rivalry "stands as a vivid illustration of what it means to be deeply affected by postmemory" (2004: 703). It is worth noting also that photographs of dead Anja function as transitional objects for mourning, which makes Vladek's second wife Mala jealous. In one panel, she reproaches Vladek: "You keep photos of her [Anja] all around your desk - like a shrine" (1986: 104).

Art's trauma requires psychotherapy, and this is provided by his Czech psychoanalyst Pavel, who is himself a survivor of Terezin and Auschwitz. When Art complains about his complicated relationship with his father, and belittles his own accomplishments in comparison to his father's achievement of surviving Auschwitz, Pavel must remind him: "But you weren't in Auschwitz... you were in Rego Park" (1991: 44, ellipses in original). The psychoanalyst suggests that even Art's father feels guilty because he has survived while the others have not. Clinical studies describe how many survivors suffer from a sense of guilt for the same reason; however, Pavel's point is that Vladek has transmitted his own survivor's guilt onto Art. Art's meetings with the psychoanalyst indicate that he defends himself against total identification with the victims of the Holocaust. Spiegelman as an artist is aware of the ethical problem of the appropriation of the Holocaust by the post-Holocaust generation. To avoid this danger, he uses various strategies ranging from irony and humor to the variety of graphic means distancing him from the Holocaust, the most apparent of which is the aforementioned use of animal imagery.

What depresses Art even more is the problem of the artistic representation of the Holocaust. Many writers have doubted the possibility of expressing experience which is beyond our understanding, ${ }^{8}$ and Art is well aware of the difficulties 
involved in finding adequate words for the historical trauma of the Holocaust. He knows that the sheer horror of reality surpasses any work of the imagination. His own lack of direct experience only compounds this problem. His own chosen genre, the comic book, only heightens his uncertainty. The question of the adequacy of this form stems from the general notion of comics as a lowbrow genre. This dismissive approach to comics, however, ignores the rapid development of the form which has evolved from cartoons and comic strips of yellow journalism through mainstream superhero comics to complex graphic narratives. Hillary Chute in her essay "Comics as Literature? Reading Graphic Narrative" does not treat comics as a lowbrow genre but as a medium whose hybridity of words and images allows conveying various serious topics. In her view, "the most important graphic narratives explore the conflicted boundaries of what can be said and what can be shown at the intersection of collective histories and life stories" (Chute 2008: 459). For her and many other theoreticians who consider comics as a part of literature, this form offers many innovative possibilities. ${ }^{9}$ Spiegelman's Maus attests to these opinions and confirms that graphic narrative has the capacity to present a traumatic personal and collective history. According to Chute, the authors of graphic narratives (including Spiegelman) refuse to show this history "through the lens of unspeakability or invisibility, instead registering its difficulty through inventive (and various) textual practice" (2008: 459).

Aaron Meskin also recognizes comics as a hybrid art; however, he disagrees with Chute's and DeKoven's concept of the hybridity of graphic narratives expressed in "Introduction: Graphic Narrative" in which they treat images as "a separate narrative thread that moves forward in time in a different way than the prose text" (2006: 769). Meskin argues that by blending words and pictures both components "determine narrative content in standard comics by working together" and "create a unified, albeit complex, whole" (2009: 235). Nevertheless his notion of hybridity does not consist in the relation between images and text (he admits preponderance of image over text) but in the diachronic view of comics, following the combination of literature with pictorial narrative and printmaking in their historical development. Considering values of great works of literature and comics and all conditions for categorization of comics as literature, he does not give a univocal answer whether comics falls into the category of literature, yet he admits their rising social status and respect among literary critics and the emergence of what can be labeled as the comics canon. This canon definitely includes Spiegelman's Maus which "not only became the classic work of comics but also found its way into the general consciousness" (Náhliková 2009: 189).

The question of the categorization and social status of comics may seem rather academic; nonetheless it is relevant because it helps to understand the causes of Art's artistic doubts that have traumatizing effects on him. Yet, here we should distinguish between Art as a character/narrator of the graphic novel and Art Spiegelman as its author. Spiegelman's artistic but also theoretical work indicates that he is well aware of the creative potential of graphic narratives. After all, his later graphic novel In the Shadow of No Towers (2004), that is his artistic 
response to the terrorist attack against The World Trade Center on 11 September 2001, confirms it. The book is pervaded with numerous allusions to old comics figures and contains even Spiegelman's own versions of classic comic strips, set in the new context of American national trauma. Spiegelman revived in them "the ghosts of some Sunday Supplement stars born on nearby Park Row about a century earlier" (Spiegelman 2004: 8), for example the Yellow Kid, Little Nemo, Maggie and Jiggs from Bringing Up Father, or, last but not least, the legendary Krazy Kat. In his version, Happy Hooligan, Frederick Burr Opper's figure, becomes a "hapless hooligan", subverting a new wave of nationalism and jingoism after the trauma of 9/11. Spiegelman even incorporated special appendix, "The Comic Supplement", in his book in which he gives the reader an overview of the historical development of comics, published in installments in Sunday newspaper supplements, especially in newspapers of the tycoons of American journalism at the turn of the $19^{\text {th }}$ century, Joseph Pulitzer and William Randolph Hearst. In finding startling parallels between classic comic strips and the 9/11 events, Spiegelman converts traumatic history into narrative memory and expresses "the vernacular protest against self-important official rhetoric" of the Bush administration (Versluys 2009: 66). Nevertheless, his employment of old comics characters and "The Comic Supplement" in particular also reveal his passion for comics as a medium.

Those readers of Maus who persistently hold an elitist view of comics, regarding it as unworthy of high culture, may have considered Spiegelman's book as a denigration of the legacy of the Holocaust. However, this approach ignores one of the hallmarks of Spiegelman's work - his sense of irony. We should read his Maus as an ironic, alternative comix response to Disney's Mickey Mouse and other comics figures embraced by popular culture. In so doing, Spiegelman has contributed to the artistic emancipation of graphic narratives. Moreover, Maus can be also treated as the cartoonist's ironic reaction to the introductory motto of Maus II, which quotes a German anti-Semitic newspaper article, published in Pomerania in the mid-1930s:

Mickey Mouse is the most miserable ideal ever revealed... Healthy emotions tell every independent young man and every honorable youth that the dirty and filth-covered vermin, the greatest bacteria carrier in the animal kingdom, cannot be the ideal type of animal... Away with Jewish brutalization of the people! Down with Mickey Mouse! Wear the Swastika Cross! (1991: 3)

Considering Art as a character in Maus, his uncertainty caused by the general undervaluation of the genre of comics results in his creative crisis in which he despairs of ever completing Maus. In one caption he says to Françoise: "I can't even make any sense out of my relationship with my father... How am I supposed to make any sense out of Auschwitz... of the Holocaust" (1991: 14, ellipses in original).

The metanarrative passages of Spiegelman's Maus are very important, because they raise the moral question of who has the right to represent the Holocaust. 
How can an assimilated Jew with no direct experience of the camps build his own career and success on the suffering of others? For Spiegelman, making art (and money) from the suffering of millions of victims is unacceptable. Therefore, the huge commercial success of the first volume of Maus does not make him happy, but on the contrary makes him feel even more depressed. He symbolizes his sense of inauthenticity and inadequateness by depicting himself in a mouse mask. The relativity and evanescence of artistic achievement is conveyed at the beginning of the section called "Auschwitz (Time Flies)" by a graphic pun - flies buzz around a depressed Art while he sits at a drawing table under which lies a huge heap of naked corpses.

Animal masks are used to signify inauthenticity, the exact opposite of what Art is striving for in his search for artistic and historical truth. Throughout the book, he struggles to ensure that his work remains genuine, and tries to avoid falsifying the truth. Spiegelman uses various devices to this end, inserting maps, diagrams, sketches, plans and photographs into Art's and Vladek's narratives. Unfortunately, not even photographs can capture reality in all its complexity. For Lentin, "Holocaust photographs often serve as shorthand representations of the whole crime" (2004: 9). In some cases, they can even distort the truth. Almost at the end of the $2^{\text {nd }}$ volume of Maus there is a photograph of Vladek posing in a clean camp uniform for a photographer after the liberation of the camp. Vladek borrowed this uniform for making a souvenir picture. Vladek's calm, peaceful appearance and the curtain in the background only underline the staged artificiality of the whole picture that could well serve as the Nazi propaganda about good treatment of prisoners in concentration camps. It reveals nothing about their suffering and is far away from reality. Yet its inclusion points to the serious problem of the (mis)representation of the wartime trauma.

A similar problem arises from the text of Vladek's testimony, as taken from Art's interview tapes. Can it be regarded as historical truth? It would be unfair to accuse Vladek of willful falsification or manipulation of the truth, and he cannot be classified as an unreliable narrator, a character type common in postmodern fiction. Yet, memory, as we know, often betrays us and may not always be precise. Art challenges his father over inconsistencies in his narrative when questioning the length of time he spent imprisoned in Auschwitz. Problems with the precision of memory are of particular importance in connection with trauma, because the unfamiliarity and extremity of the traumatic situation is great enough to prevent comprehension and integration of this situation into the mind of the victim. Consequently "the transformation of the trauma into a narrative memory that allows the story to be verbalized and communicated, to be integrated into one's own, and others', knowledge of the past, may lose both the precision and the force that characterizes traumatic recall" (Caruth 1995: 152). According to van der Kolk and van der Hart, "many traumatized persons [...] experience long periods of time in which they live, as it were, in two different worlds: the realm of the trauma and the realm of their current, ordinary life. Very often, it is impossible to bridge these worlds" (1995: 176). 
Vladek's multiple traumas shape his behavior after the war. Growing old, he develops a number of uncongenial character traits - an almost unbearable frugality, pedantry, authoritativeness. His sermonizing and penny-pinching often embarrass Art and complicate his relationship with his father. From Vladek's narrative we gain the impression that the Holocaust has never ended for him. He seems to be convinced that the security he enjoys in his life is transitory, because disaster can come any moment. In his dialogues with Art recollecting his suffering in the concentration camp, he tends to confuse time, giving his son instructions on how to survive in extreme situations. "If you want to live, it's good to be friendly" (1991: 62), he tells Art as if he has forgotten that he is not in Auschwitz but in America. Vladek's testimony fits well van der Kolk's and van der Hart's concept of traumatic memories. According to them, "[ $t$ ]hey [traumatized persons] often can tell the story of their traumatization with a mixture of past and present, but their current life is characterized by doubt and humiliation, by feelings of guilt and shame; past meaning schemes determine the interpretation of the present" (1995: 178). Vladek's sense of guilt is connected with the loss of his son, since he blames himself for his failure to save Richieu's life. He is convinced that the wrong decisions which he made resulted in the death of his son, and he assumes this responsibility for his death even though it is almost certain that he could have done nothing to save Richieu.

Although Vladek's character flaws are understandable given his traumatic past, they remain a source of suffering for his second wife Mala, another Holocaust survivor. Vladek unreasonably suspects her of dispossessing him of his life savings. His marriage to Mala is one of endless quarrels and reproaches. Mala is traumatized by the awareness that she is an imperfect substitute for Anja, Vladek's first wife (a feeling comparable to Art's relationship with Richieu). Anja's tragic death was an irretrievable loss for Vladek, the cause of his mourning and melancholy, and he remains unable to cope with this loss for the rest of his life. His behavior seems to confirm Herman's assertion that "[m]ourning is the only way to give due honor to loss; there is no adequate compensation" (1997: 190).

Anja's trauma has been silenced. Art is plagued by remorse for his unwillingness to listen to his mother during her life despite his undeniable love for her. We will never learn Anja's story from her own perspective because, as Art discovers, Vladek has destroyed her diaries, a paradoxical move given his habit of hoarding useless junk in his apartment. As Art's work depends on the memories of direct witnesses to the Holocaust, it is not surprising that his father's decision to burn Anja's diaries upsets him. He regards it as a betrayal of the legacy of his mother and of those who perished in the Holocaust. The loss is irrecoverable, and renders a multi-perspective record of the terrifying historical events impossible. Art knows this and calls his father a "murderer" at the end of the first volume of Maus (1986: 159). ${ }^{10}$ In his eyes, Vladek has "murdered" his mother's memories. As a matter of fact, he realizes that "his father's entire story is haunted by Anja's lost story" (Young 2003: 34). His pain is deepened after he learns that the diary contained his mother's hope that her son would one day show an interest in her 
testimony. However, instead of his mother's testimony, he hears only silence. Her words have been incinerated, like the millions of victims burned in the crematoria of the death camps.

To conclude, Art Spiegelman ranks among the second generation writers who respond to the persistent effects of the Holocaust in the present and view this historical tragedy from a new perspective. While most of these writers are concerned with the experiences of the children of survivors in America, Spiegelman's approach seems to be more complex. Similarly to the other authors of his generation, he also represents the Holocaust in relation to the present, but the multi-layered narrative structure of his Maus enables him to synthesize memory with postmemory. Both of them are integral parts of this work. In this respect, due to Spiegelman's integrative narrative techniques, the memory of the survivor (Vladek) and the postmemory of his child (Art) do not appear to be in opposition, despite the obvious tension and very complicated relationship between father and his son. Spiegelman's awareness of the nature of trauma manifests itself in the blurring of temporal boundaries, graphically expressed in various innovative ways, for instance by merging the present with the past within a frame or beyond it (when his drawings stretch beyond the gutters). The form of a graphic narrative enables Spiegelman "to travel in another realm" (McCloud 1993: 36), in this case in the time of World War II, and also to convey Art's temporal and spatial relocation as the result of intergenerational transmission of trauma. However, through various formal means (in particular by using anthropomorphized animals) Spiegelman distances himself from his parents' trauma, and thus he avoids the ethically unacceptable (or, at least problematic) appropriation of the experience of the Holocaust. This distance is lost only in the embedded comic strip "Prisoner on the Hell Planet", in which the cartoonist conveys his firsthand trauma, but even here he connects his personal trauma with the historical trauma of the Holocaust. Moreover, an important part of Maus are its metanarrative passages dealing with the pitfalls of the artistic representation of the Holocaust, which for Art are traumatizing factors in themselves.

Spiegelman's interest in post-Holocaust identity, hand in hand with his awareness of the impact of his parents' trauma, connects him with the other authors of his generation. Although the narrator-protagonist Art was not exposed to the trauma of the Holocaust directly, his identity has been profoundly shaped by the tragedy of his parents, the direct witnesses of the Nazi genocide during World War II. Despite his resistance to the total identification with the past of his parents, he inevitably becomes the intergenerational recipient of their trauma. The main vehicle of this transmission is memory channeled from the father Vladek to his son Art in the form of taped testimony whereas the mother's memory is silenced. Yet we should not imagine the transfer of trauma from parents to their children as a mechanical act. It has its social, cultural and psychological dynamics ensuring that the child's trauma is by no means identical with that of parents. It is rather transformed trauma "through an imaginative investment and creation" (Hirsch 1997: 80) of the descendants of survivors. Spiegelman's Maus represents such an 
imaginative investment and creation. His graphic novel transforms Vladek's testimonial enactment of the trauma of the Holocaust into art capable of addressing subsequent generations of readers and keeping collective memory alive.

\section{Acknowledgements}

\section{This article is part of the Student Grant Competition, project SGS4/FF/2012, University of Ostrava, "Intergenerational and Transgenerational Transmission of Trauma in Contemporary Jewish American Fiction".}

\section{Notes}

1 The title of this article indicates that Spiegelman's Maus is examined from the vantage point of trauma studies. The extensive body of Maus scholarship testifies to literary critics' unceasing interest in this work. An overview of Maus criticism is given in a very useful study “Art Spiegelman's Maus: A Survivor's Tale: A Bibliographic Essay", in which her author Hye $\mathrm{Su}$ Park summarizes and classifies this criticism on the basis of thematic categories, including trauma. Her study is valuable in terms of pointing to certain gaps in the criticism related to Maus, and hence is inspiring because it calls for a broadening and enrichment of the field. This concerns especially the examination of gender, narrative form, language and critical pedagogy in Maus scholarship.

2 Since in Maus Art Spiegelman merges into his comic character Art, it is difficult to distinguish between the author as a biological person and his fictional self-representation. If we confront Art as a comic character with the biographies of Art Spiegelman, we see that the author is very faithful to the actuality of his life, attempting to suppress stylization to the maximum possible extent. Maus is a daring account of the most intimate matters in the Spiegelman family with all their imperfections, including Art's. In this respect, LaCapra is right when he points out the proximity and distance between Spiegelman and the Art-figure, concluding that the cartoonist "intentionally created ways in which Artie would not appear as a fully sympathetic character or object of transferential identification for the reader" (1998: 153). In this article Art (Artie) is viewed as a comic character because the paper does not intend to analyze its author's traumas in spite of the fact that Art obviously represents Spiegelman's alter-ego.

3 In her article "The Generation of Postmemory", Marianne Hirsch sees postmemory as "a structure of inter- and trans-generational transmission of traumatic knowledge and experience. It is a consequence of traumatic recall but (unlike post-traumatic stress disorder) at a generational remove" (2008: 106).

4 Jewish identity shaped by the Holocaust in Maus is explored in Michael E. Staub's article "The Shoah Goes On and On: Remembrance and Representation in Art Spiegelman's Maus". Also Andrew Gordon's study "Philip Roth's Patrimony and Art Spiegelman's Maus: Jewish Sons Remembering Their Fathers" touches this issue, viewed from the perspective of a rather complicated relationship between a Jewish father and son. A similar approach in an examination of Art's identity, shaped by the tense father-son relationship, appears already in earlier studies, e.g. in Michael Brown's article "Of Mouse and Men. Problems of Asserting Identity in a Post-Holocaust Age".

5 Comix in its different spelling suggests avant-garde magazines in which comics were published; Spiegelman himself was involved in the underground magazines Arcade, The Comics Revue, Breakdowns, and, together with his wife Françoise Mouly, in the magazine Raw. 
It is pertinent especially to the representation of Art's father, whose agonized expression conveys an unpronounceable despair over the loss of his beloved Anja. The overall depression is reinforced by the black background of the pages and by the use of graphic hyperbole which distorts reality. The highly emotional content of Spiegelman's drawings evokes terror, compressed into a limited space of individual frames.

Aaron Hass in his monograph dealing with the second generation claims that "guilt and depression are common motifs manifested in the offspring of survivors. Guilt for not being good enough. Guilt for growing up in easier circumstances. Guilt for feeling anger toward one's parents. Guilt for inflicting further pain on a survivor" (2001: 41).

For example the Jewish writers Isaac Rosenfeld and Hannah Arendt were skeptical of the fictional representation of the Holocaust. Some writers, such as Elie Wiesel and George Steiner, wrote about silence as a possible response to these events beyond our comprehension. Cynthia Ozick asserted that the terror of the Holocaust should be recorded only in nonfiction. According to her, if it is embraced by the imagination, there is always a danger of the distortion of historical reality. Yet, even she (like Wiesel and Steiner) was driven to address the tragedy of the Jews through fiction, e.g. in The Messiah of Stockholm (1987) and The Shawl (1989). In her interview with Elaine M. Kauvar, she confessed: "I don't admire that I did it. I did it because I couldn't help it. It wanted to be done" (1993: 391). To present the enormity of Nazi genocide in an "imaginable" way, some writers look for parallels in previous history, for example in the blood libel trial of Mendel Beilis in Kiev in 1911, which inspired Bernard Malamud to write his novel The Fixer (1966), a parable of the Holocaust. An increasing number of scholarly studies deal with comics, graphic novels in particular, as a serious artistic form. Among them, we can name a seminal monograph by Joseph Witek Comic Books as History: The Narrative Art of Jack Jackson, Art Spiegelman, and Harvey Pekar (1989) and Douglas Wolk's Reading Comics: How Graphic Novels Work and What They Mean (2007). Jewish comics are examined by critics Derek Parker Royal and Paul Buhle, the editor of Jews and American Comics: An Illustrated History of an American Art Form (2008), who is the author of an interesting study on Spiegelman "Of Mice and Menschen: Jewish Comics Come of Age" (1992). One of the most fervent propagators of comics is Scott McCloud, who, in some of his works, unusually deals with the theory of this medium in the form of comics. Comic books and graphic novels are examined in their historical context in the collection of essays The Rise and Reason of Comics and Graphic Literature: Critical Essays on the Form, edited by Joyce Goggin and Dan Hassler-Forest (2010).

In this respect, Art criminalizes his father like his mother in "Prisoner on the Hell Planet".

\section{References}

Brown, Michael (1993) "Of Mouse and Men. Problems of Asserting Identity in a Post-Holocaust Age". Studies in American Jewish Literature 12, 135-140.

Buhle, Paul (1992) "Of Mice and Menschen: Jewish Comics Come of Age". Tikkun 7 (2), 9- 16.

Buhle, Paul (ed.) (2008) Jews and American Comics: An Illustrated History of an American Art Form. New York: The New Press.

Caruth, Cathy (1995) "Recapturing the Past: Introduction". In: Caruth, Cathy (ed.) Trauma: Explorations in Memory. Baltimore and London: The Johns Hopkins University Press, 151-157.

Caruth, Cathy (1996) Unclaimed Experience. Trauma, Narrative, and History. Baltimore and London: The Johns Hopkins University Press.

Chute, Hillary (2008) "Comics as Literature? Holocaust Reading Graphic Narrative". PMLA 123 (2), 452-465.

Chute, Hillary L. and Marianne DeKoven (2006) "Introduction: Graphic Narrative". Modern Fiction Studies 52 (4), 767-782. 
Eaglestone, Robert (2004) The Holocaust and the Postmodern. Oxford: Oxford University Press.

Elmwood, Victoria A. (2004) “"Happy, Happy Ever After': Transformation of Trauma between the Generations in Art Spiegelman's Maus: A Survivor's Tale”. Biography 27 (4), 691-720.

Franciosi, Robert (2003) “Art Spiegelman”. In: Kremer, S. Lillian (ed.) Holocaust Literature. An Encyclopedia of Writers and Their Work. Vol. 2. New York: Routledge, 1199-1207.

Goggin, Joyce and Dan Hassler-Forest (eds.) (2010) The Rise and Reason of Comics and Graphic Literature: Critical Essays on the Form. Jefferson, NC: McFarland.

Gordon, Andrew (2005) "Philip Roth's Patrimony and Art Spiegelman's Maus: Jewish Sons Remembering Their Fathers". Philip Roth Studies 1, 53-66.

Hass, Aaron (2001) In the Shadow of the Holocaust: The Second Generation. Cambridge: Cambridge University Press.

Herman, Judith Lewis (1997) Trauma and Recovery. New York: Basic Books.

Hirsch, Marianne (1997) Family Frames: Photographs, Narrative and Postmemory. London: Harvard University Press.

Hirsch, Marianne (2008) "The Generation of Postmemory". Poetics Today 29 (1), 103-128.

Hungerford, Amy (2003) The Holocaust of Texts. Genocide, Literature, and Personification. Chicago: University of Chicago Press.

Kauvar, Elaine M. (1993) “An Interview with Cynthia Ozick”. Contemporary Literature 34 (1993), 359-394.

LaCapra, Dominick (1998). History and Memory After Auschwitz. Ithaca, N.Y.: Cornell University Press.

LaCapra, Dominick (2001) Writing History, Writing Trauma. Baltimore and London: The Johns Hopkins University Press.

Lentin, Ronit (2004) "Introduction: Postmemory, Unsayability and the Return of the Auschwitz Code". In: Lentin, Ronit (ed.) Re-Presenting the Shoah for the Twenty-First Century. New York: Berghahn Books, 1-24.

McCloud, Scott (1993) Understanding Comics. An Invisible Art. New York: Paradox Press.

Meskin, Aaron (2009) “Comics as Literature?" British Journal of Aesthetics 49 (3), 219-239.

Náhliková, Michaela (2009) "Will Eisner as a Cult Comics Writer: From The Spirit to The Plot". In: Arbeit, Marcel and Roman Trušník (eds.) Cult Fiction and Cult Film: Multiple Perspectives. Olomouc: Palacký University Press, 185-199.

Park, Hye Su (2011) “Art Spiegelman's Maus: A Survivor's Tale: A Bibliographical Essay”. Shofar: An Interdisciplinary Journal of Jewish Studies 29 (2), 146-164.

Schwab, Gabriele (2010) Haunting Legacies: Violent Histories and Transgenerational Trauma. New York: Columbia University Press.

Sicher, Efraim (2005) The Holocaust Novel. New York: Routledge.

Spiegelman, Art $(1986,1992)$ Maus. A Survivor's Tale. Part I: My Father Bleeds History. New York: Pantheon.

Spiegelman, Art (1991, 1992) Maus. A Survivor's Tale. Part II: And Here My Troubles Began. New York: Pantheon.

Spiegelman, Art (2004) In the Shadow of No Towers. New York: Pantheon.

Staub, Michael E. (1998) "The Shoah Goes On and On: Remembrance and Representation in Art Spiegelman's Maus". MELUS 20 (3), 33-47.

van der Kolk, Bessel A. and Onno van der Hart (1995) "The Intrusive Past: The Flexibility of Memory and the Engraving of Trauma". In: Caruth, Cathy (ed.) Trauma: Explorations in Memory. Baltimore and London: The Johns Hopkins University Press, 158-182.

Versluys, Kristiaan (2009) Out of the Blue: September 11 and the Novel. New York: Columbia University Press.

Witek, Joseph (1989) Comic Books as History: The Narrative Art of Jack Jackson, Art Spiegelman, and Harvey Pekar. Jackson, London: University Press of Mississippi.

Wolk, Douglas (2007) Reading Comics: How Graphic Novels Work and What They Mean. Cambridge, MA: Da Capo, 2007. 
Young, James E. (2003) “The Holocaust as Vicarious Past: Art Spiegelman's Maus and the Afterimages of History". In: Bernard-Donals, Michael and Richard Glejzer (eds.) Witnessing the Disaster: Essays on Representation and the Holocaust. Madison: The University of Wisconsin Press, 23-45.

Stanislav KolÁr̆ is an associate professor at the Department of English and American Studies, Faculty of Arts, University of Ostrava, Czech Republic, where he teaches courses on American Literature and American Studies. He was an IREX visiting scholar at Brandeis University, Massachusetts, and Fulbright fellow at the University of California in Berkeley. In his research, he focuses on Jewish American literature, the representation of the Holocaust in literature, and American ethnic literatures. He is the author of monographs Evropské kořeny americké židovské literatury (1998, The European Roots of Jewish American Literature) and Seven Responses to the Holocaust in American Fiction (2004). With the co-authors Zuzana Buráková and Katarína Šandorová he has published a monograph entitled Reflections of Trauma in Selected Works of Postwar American and British Literature (2010).

Address: doc. PhDr. Stanislav Kolář, Dr., Department of English and American Studies, Faculty of Arts, University of Ostrava, Reální 5, 70103 Ostrava, Czech Republic. [Stanislav.Kolar@osu.cz] 
